G 103

\title{
わが国における悪性胸膜中皮腫死亡数の将来予測
}

\author{
第 1 報：胸膜中皮腫関連死亡に関する I C D 死因分類の変遷
}

○車谷典男 (奈良医大衛生学)・名取雄司(ひらの刍戸ひまわり診療所)

高橋謙(産業医大環境疫学) - 村山武彦(早稲田大理工・複合領域)

【はじめに】わが国の石綿輸入量は、1974 年の35万ト ンをピークとして減少基調に転じ、特に 1990 年以降 は急速な減少を見せている。一方、石綿関連疾患である 覀性胸膜中皮腫死亡数は、近年増加傾向にあることが報 告されている。潜伏期間による初回石綿ばく露からの発 症の遅れを示すものと考えられるが、今回、わが国の人 口動態統計資料と Age-Cohort モデルを用いて、胸膜中皮 腫死亡数の将来予測を試みたので報告する。本第 1 報は、 予測の基礎となる死因分類の変遷に関する検討結果を述 べる。【資料】1. 死因別死亡数：胸膜の悪性新生物を 独立コードとして分類したICD 7 実施年の 1958 年 から、最新資料年の 2000 年までの間の人口動態統計 を基礎資料とした。 2. 分類対応表：I C D 7 78 は 「疾病、傷害および死因統計分類提要（昭和 43 年 版）」を、I C D 8 99 は厚労省統計情報部から入手し た対応表を、I C D $9 \Leftrightarrow 10$ は「I C D-10・I CD9 分類項目対応表」（厚労省）を、それぞれ参照した。

【結果】1.ICD分類の変遷：胸膜中皮腫関連死亡の I C D 分類は表 1 のように整理された。VI（I C D 7 ）からIX （ＩＣＤ９）までは、上位コードは異なっているが、い ずれも胸膜の悪性新生物に関する固有コードが存在した。 胸膜中皮腫としての独立コードが設けられたのは199 5 年実施のX（ＩＣＤ１０）からである。２. 胸膜中皮 腫関連死亡数の経年推移：図 1 にUI 以降 2000 年まで の 43 年間の関連死亡数の推移を示す。合計死亡数は 6 8 年に急峻な立ち上がりを見せ、それまで 1 桁であった ものが 3 桁台となり、78年まで続いている。79年に は 2 桁台に戻った後、現在まで増加傾向にある。こうし た不規則変動はVIII（IＣＤ８）に起因するものである。 分類対応表では、VIIの 163.0 は 67 年時点で死亡数約 8 千人のVII 163 (原発・続発の別不明の肺の悪性新 生物）の枝分かれを受けていて、その一部（200人前
図1. 胸膜中皮腫関連死亡数の経年推移

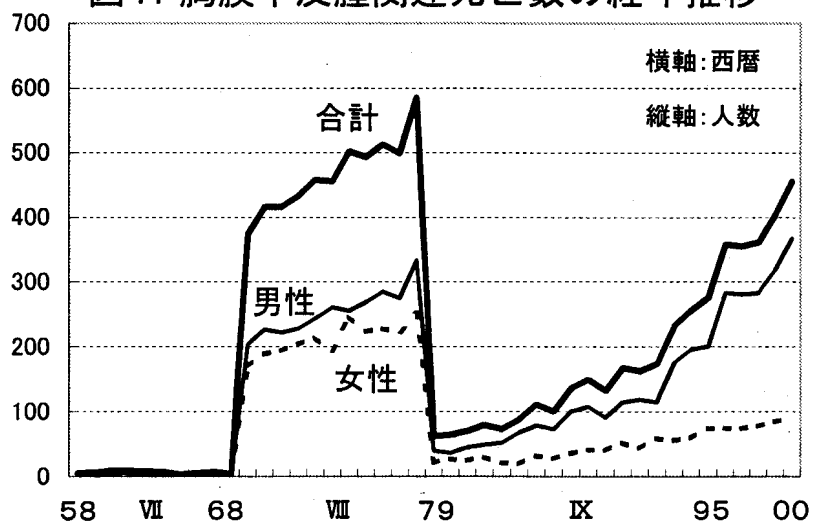

後）が 163.0 に分類された結果と思われた。なお、男 女とも同様の推移を示すが、男性の死亡数が一貫して女 性よりも多く、最近程その差は大きい。 3. XからXへの 推移：男性について述べる。IXの163の死亡数は87 年から 100 人を超え、94年には 196 人に達してい る。163は 4 つの 4 析コードに細分されるが、死亡数 の $99 \%$ 部位不明の 163.9 （表 1 ）にコードされて いた。分類対応表では、163はXのC 45.0 とC 38 . 4 （表 1 ）に枝分かれする。C 45.0 とC 38.4 の合 計と 163 との死亡数推移や年㱓構成割合等の連続性の 検討では、これらのコード間で不連続性を示唆する結果 は観察されなかった。【結論】わが国の悪性胸膜中皮 腫関連死亡数は、V四前後で明らかな不規則変動が認めら れた。IXの163には中皮腫と中皮腫でない胸膜悪性新 生物が含まれているが、その比はXのC 45.0（6年間 で 1734 人）とC 38.4 (同 127 人）との死亡比と 期待できる。この比に基づく 163 のうちの推定中皮腫 死亡数と、XのC 45.0 の死亡数を用いた悪性胸膜中皮 腫の死亡数に関する将来予測の結果を第 2 報で述べる。

\section{表1. 胸膜中皮腫関連死因のICD分類の変遷}

\begin{tabular}{|c|c|c|c|c|}
\hline ICD & 期間 & コード & 疾患名 & 説明（疾患名は一部略記・括弧内は I C D コード） \\
\hline VII & 1958 - & 162.2 & 胸膜 & $\begin{array}{l}\text { 気管支・気管・原発が明示された肺の悪性新生物（162）の下位 } \\
\text { 分類。他の下位分類に気管支と肺（162.1）など3つある。 }\end{array}$ \\
\hline VIII & 1968 - & 163.0 & 胸膜 & $\begin{array}{l}\text { その他・詳細不明の呼吸器の悪性新生物（163）の下位分類。他 } \\
\text { の下位分類には縦隔 (163.1) など3つある。 }\end{array}$ \\
\hline $\mathbf{X}$ & 1979 - & 163 & 胸膜の悪性新生物 & $\begin{array}{l}\text { 下位分類として、部位不明の胸膜悪性新生物（163.9）、壁側胸 } \\
\text { 膜の悪性新生物（163.0）など } 4 \text { つある。 }\end{array}$ \\
\hline $\mathrm{X}$ & 1995 - & C45.0 & 胸膜中皮腫 & $\begin{array}{l}\text { 中皮腫（C45）の下位分類。胸膜の悪性新生物（中皮腫は除く） } \\
\text { はC38.4にコードされている。 }\end{array}$ \\
\hline
\end{tabular}

